\title{
The actuopaleontological studies on Cuban scleractinians and coral reefs of half a century ago are not over
}

\author{
Vassil N. Zlatarski \\ Independent Scientist, 131 Fales Road, Bristol, RI 02809, USA, vzlatarski@gmail.com. \\ (Accepted in revised form: November 2017)
}

With great respect to the memory of Alberto Korda (14.09.1928 - 25.05.2001), who already being a world-famous photo-artist, and after only a brief conversation on the Havana coast, embraced the idea of investigation into the Cuban corals, and with his unique underwater pictures and enthusiastic support made the coral project real.

\begin{abstract}
Gathering and studying a rich collection of fossil corals in Bulgaria led to the definition of various new taxa, but highlighted the gaps in our knowledge of fossil Scleractinia. I needed to learn from living corals. An actuopaleontological project with massive sampling of all phenotypes following coral life in depth in Cuba (1970-1973) showed extraordinary scleractinian variability and led to "heresy" regarding the conventional Caribbean taxonomy. Subsequent fundamental new knowledge challenged Scleractinia taxonomy and justified the results of the investigation of the Cuban corals, through continuing contributions to: holistic approach to scleractinian species; integrative character of coral taxonomy; new paleobiological perspectives and tasks for study; and the evolutionary benefits of hybridization for reef survival. Continuing research can be supported by: an $80 \%$ preserved collection; a scientific audiovisual documentary; a monograph in Russian, French, and soon Spanish; and a substantially and rarely preserved coral life and reef ecosystem.
\end{abstract}

Zlatarski, V.N. 2017. The actuopaleontological studies on Cuban scleractinians and coral reefs of half a century ago are not over. Geologica Balcanica 46 (2), 111-116.

Keywords: Scleractinia, reefs, actuopaleontology, variability, phenoid, taxonomy.

\section{WHY ACTUOPALEONTOLOGICAL AND IN CUBA?}

In 1955 , as a university freshman, I followed the advice of the brilliant, recently graduated geologist, Juli Stephanov (1932-1966) not to waste time and to start working with fossils and paleontology to help me learn about the history of life. As a junior, my professor of Paleontology, Vassil Tzankov (1905-1986), suggested studying fossil corals, since they were found in many places in Bulgaria and because of my command of the German language. As a result of my student field work, by 1958, the University of Sofia had a rich fossil coral collection. Conducting good research required learning from the best international specialists, but I did not have any idea who and where they were. As a result, my professor directed me to review, one by one, the entire paleontological literature available in Bulgaria at that time (more than 20,000 books and journal issues). The answer became clear: the Parisian coral school. I learned the name of the leader of this paleontological team, James Alloiteau, and his title, Directeur de Recherches au C.N.R.S. Today, I realize how self-confident it was for a Bulgarian student in 1958 to send a letter from Sofia to Paris, even more so because it was merely addressed to this name and title, with no address. Two weeks later, I received an extremely kind reply, starting with "Mon cher ami." This was the beginning of a regular correspondence for numerous consultations, help with specimens, and access to rare publications on corals. But it turned out that a professional coral study required specialization in person. Unfortunately, the existing reality did not favor my traveling abroad. Without any hesitation, I sent invitation to Paris. Dr. Jean-Pierre Chevalier, a senior member of the Paris team, kindly accepted and spent a month in Bulgaria in 1961, as the first Western geologist to 
visit after the Second World War. He generously provided a personal intensive course of specialization. Soon, it became evident that the efforts to describe and operate with taxa required a command of nomenclature. This experience came from volunteering editorial work (1962-1964) for the Bulgarian translation of the International Code of Zoological Nomenclature. Species identification of the rich collection revealed many new taxa and remarkable coral variability, which posed questions and difficulties for coral taxonomy and required mastering of the notion of the species concept in corals (Zlatarski, 1967c, 1969). Using paleontological literature in various languages led me to the idea of preparing a multi-language glossary of equivalent terms for Scleractinia. The necessity for collegial collaboration prompted me to start promoting the idea of an International Symposium on Fossil Corals, which was warmly received by Prof. B.S. Sokolov in 1967 (Zlatarski, 1967c) and realized successfully by him four years later. The Bulgarian fossil material brought to light the previously unknown rich life of corals and reefs during the Early Cretaceous. As a result, several new species, genera, and even a new family were published for the first time (Beauvais and Zlatarski, 1966; Zlatarski, 1966, 1967a, b, 1968a, b, 1970). But I was not satisfied that we possessed sufficient knowledge to justify continuing with the conventional taxonomic approach. In 1968, during the defense of my thesis on Lower Cretaceous corals (Zlatarski, 1968c), when provided an opportunity to make a closing statement, I shared my reservations and my belief in the need to learn from living corals. The dream to use the present as a key to the past became a reality when the Geological Institute of the Bulgarian Academy of Sciences (BAS) received the task of geological mapping of the Cuban Province Las Villas. I was happy to accept the position of field geologist and to be sent to Cuba for a two-year mission, from 1969 to 1971.

\section{WORK IN CUBA}

Our group arrived in Havana in September 1969. I brought with me my dream for actuopaleontological research on scleractinians and coral reefs but no clue on how to realize it. Using the hours after the work of preparing for six months of geological field work in Central Cuba, I established contacts with zoologists and those interested in underwater research. In two weeks, I submitted a proposal to the President of the Academia de Ciencias de Cuba (ACC) for the study of recent coral fauna. My first encounter with the internationally renowned Cuban photo-artist Alberto Korda, who was exploring a new interest in underwater photography, was very encouraging. He enthusiastically accepted and supported the project and recommended as a diving officer of our future team the most experienced Cuban diver, Juan Álvarez.
I left Havana for six months of geological mapping but did not abandon my commitment to the living coral world. On weekends, I joined a local spearfishing group, my only opportunity to obtain practical experience in the Cuban marine environment. Back in Havana, with Korda and Juan on our days off, we started scuba explorations, establishing our methodology of underwater transects from the beach, with stations, following coral life to the possible depth by sampling all coral species and phenotypes and working out our methods for photographic documentation. This was the beginning of our collection. Marine biologist Nereida Martínes Estalella joined the team as a researcher of organisms associated with Scleractinia.

We were invited to prepare the diving transects and stations for the First Scientific Symposium of the Confédération Mondiale des Activités Subaquatique, occurring that same year in Cuba. The reception of our presentation at this event supported our methodology and results. This recognition, and the growing scientific interest in underwater scientific studies, led to a new project in the contract between BAS and ACC. After my second geological field work, in 1961, I joined the Instituto de Oceanología ( $\mathrm{IdO}), \mathrm{ACC}$, for a two-year project, "Recent Coral Fauna of Cuba."

I went to Cuba to observe living corals in their natural habitat and to learn from them, with the goal of resolving the paleontological problems of my fossil material. However, from my first scuba explorations, I was bewildered by two conventional coral doctrines, which pronounced a limited depth range for coral life and failed to account for scleractinian variability. First, direct observation of coral distribution disproved the eco-axiom that, in tropical waters, the coral world disappeared deeper than $40 \mathrm{~m}$ (Cousteau and Diolé, 1971). We sampled from a good presence of scleractinians to $70 \mathrm{~m}$ and observed them to $90 \mathrm{~m}$. In this way, the project ventured into what is now a new wave of studies dedicated to the mesophotic zone. The second surprise related to the existing Caribbean Scleractinia taxonomy, which was based on a typological species concept with clearly discrete morphospecies. In reality, many of the collected phenotypes "did not fit in the drawers" of the nominal species. This failed to account for the presence of frequent intermediate coralla, a series of samples showing gradual morphological continuity between nominal species, and even the existence of colonies displaying in their different parts the characteristics of more than one species. This led me to become an early convert to massive sampling following real coral distribution and to pay appropriate attention to the exceptional scleractinian variability of all observed phenotypes on different levels of biological organization. Our focus moved from thinking about static coral species to the dynamics of coral speciation.

Longer expeditions in the Cuban Archipelago helped us establish the types of coral reefs and their zonation. On the boat, Nereida waited for the sample 
basket and immediately separated coral-associated organisms for her research. Korda dove with two cameras. He photographed corals selected by the researcher, first in color, and then in black and white, with the number of the station. His collection of diapositives grew, offering unique, high-quality illustrations of Caribbean corals.

Back in Havana, in collaboration with the most prominent coral specialists of the time, we completed a glossary of equivalent terms for scleractinian studies in English, German, French, Italian, Spanish, Polish, Russian, and Bulgarian. It was presented together with the result of the investigation in 1971 in Novosibirsk, during the First International Symposium on Fossil Corals, and published later (Zlatarski, 1973, 1975).

After exploration of 44 transects and 194 stations, the number of coral samples approached six thousand. We decided to make the results available to colleague zoologists, paleontologists, specialists, and others interested in modern and fossil coral reefs through a scientific documentary. The production of a film of the study's results was added to the contract between BAS and ACC. A team of six scuba divers from BAS came for five months in the beginning of 1973, and, with Cuban specialists, we started filming the established coral life and reef zonation in color. The cameraman, Bogdan Jablensky, top BAS photodocumentalist and an experienced scuba diver and medic for the expeditions, surmounted countless difficulties, from a shortage of materials and air to the scarcity of water for test-developing first films. After finishing the underwater work on the documentary, in the fall of 1973, for the first time in four years, I went home for a vacation.

\section{WORK IN BULGARIA}

Back in Sofia, it took a year and a half to finish the film, "The recent coral fauna of Cuba," voiced in five languages (Bulgarian, English, French, Spanish, and Russian), later projected during scientific meetings several times in Bulgaria, Cuba, the United States, Russia, France and Mexico, and one time in each of Japan, England, Poland, Slovenia, Croatia, Georgia and Mozambique.

Unfortunately, the investigation was put on hold until, in the spring of 1975 , we were informed that Nereida would arrive in Bulgaria in four days' time, along with our entire collection. A charter plane brought 22 huge wooden boxes. The collection was opened and organized under a dome in the University of Sofia for a two-year study and photo documentation. The lack of heating in the colder months was a serious challenge for Nereida, and the researchers worked all day dressed in winter outerwear, with coats and hats.

The existing species notion and established variability with instances of not discrete morphospecies led us to apply forma as an infrasubspecific catego- ry. The project allowed us to apply the principle of actualism in a traditional, as well as reverse, manner (Khrischev and Zlatarski, 1968; Zlatarski, 2002), by developing the concept of an actuopaleontological axis. The analysis of variability prompted introducing the concept of phenoide as a graphic presentation of structure and the dynamic of species population. What was observed and developed was "heresy" to the conventional Caribbean coral taxonomy (Zlatarski and Martinez Estalella, 1980, 1982).

Nereida studied the organisms associated with Scleractinia, paying special attention to the description of Millepora. B. Jablensky came two or more times a week to take photographs of corallia and details of skeletal micromorphology (Fig. 1). After two years in Sofia, the collection was once again carefully packed in the same gigantic cases and sent back to Cuba. The largest methodically-made scientific collection of Atlantic scleractinians flew for a second time over the Atlantic.

Pursuant to the contract between BAS and ACC, Russian, French and Spanish versions of the monograph were prepared in Sofia from a Bulgarian manuscript, and the Spanish version was delivered to ACC. Participation in international coral symposia and visits to Russia, Georgia and Poland provided the opportunity for final consultations and language editing of the Russian and French versions. The Russian version was published first (Zlatarski and Martinez Estalella, 1980), followed by the French (Zlatarski and Martinez Estalella, 1982).

In early 1981, Nereida was dispatched again to Sofia, this time with Korda's diapositives, to finish the atlas with underwater color coral pictures in situ and the ecological characteristics of all Scleractinia taxa in the monograph. We finished the project, and our manuscript, with all diapositives, was delivered to ACC. Sadly, this unique atlas was not published. In my later visits to Havana, in 2001, 2002, 2003 and 2012, I worked diligently to find the manuscript and Korda's diapositives, and even contacted Alberto's family, but without success.

\section{THE INVESTIGATION CONTINUES}

The monograph was received with very positive reviews from the experts on recent Scleractinia, and in 1983 I successfully defended a thesis at the Paleontological Institute of Moscow (Zlatarski, 1983) for a degree of DSc in Biology. However, the conventional taxonomy maintained its hold on many, who continued to see and describe only "clear" species, neglecting variability. Subsequent years brought to light fundamentally new information about scleractinian variability, molecular biology, hybridization, micromorphology, microstructure, ecology, life history, paleobiology and coral populations. This new knowledge challenged the existing taxonomic prac- 

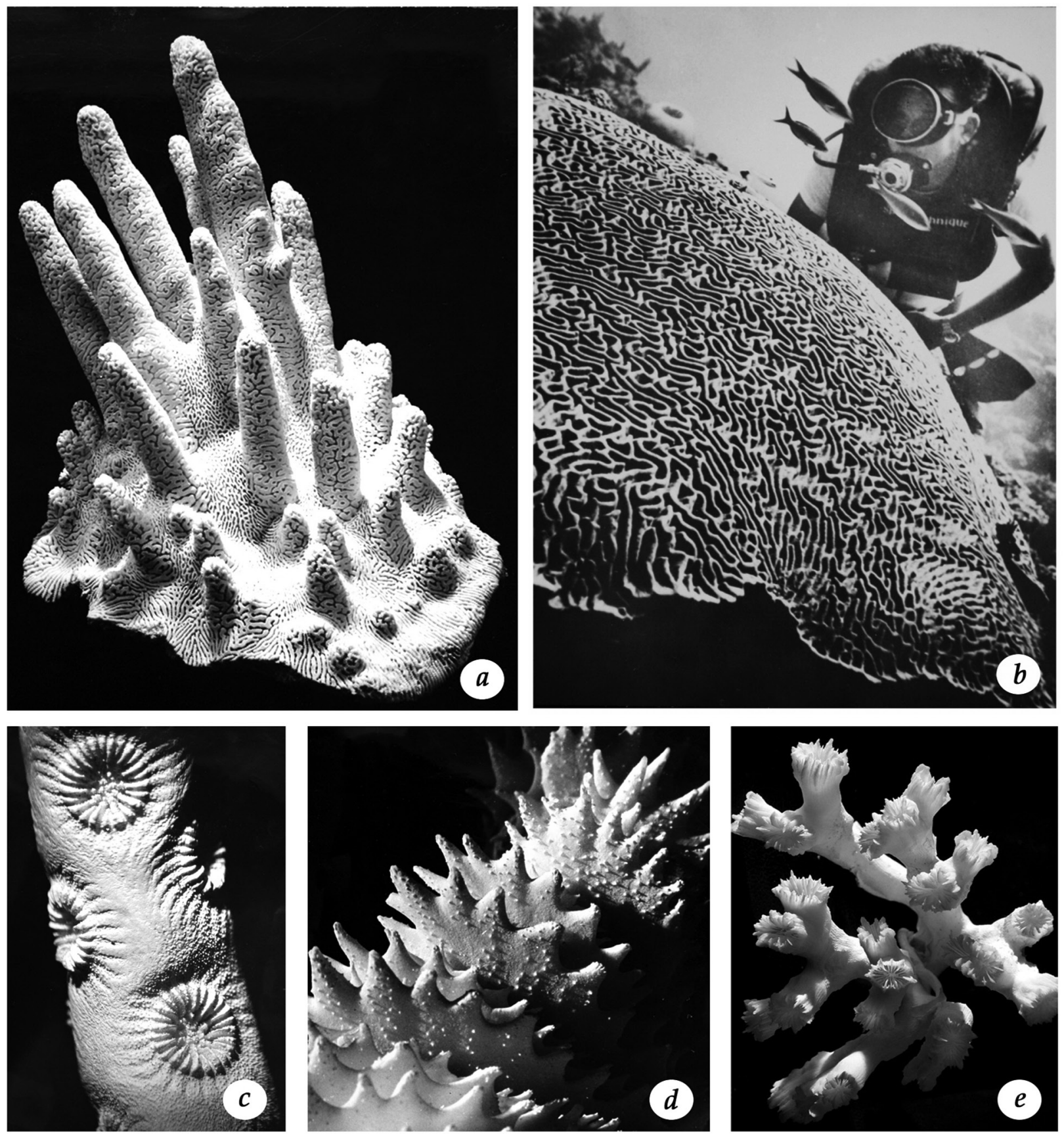

Fig. 1. Coralla, details of corallum branch and skeletal micromorphology: a) Entire majestic colony of Dendrogyra cylindrus showing intra-colony variability; the base of the colony lacking ambulacra, which according to conventional methodology was a diagnostic characteristic, $\times 0.15 ; b)$ Giant colony of Colpophyllia natans; $c$ ) Detail of branch surface of Oculina, $\times 5 ; d)$ Mussa angulosa, micromorphology, $\times 3$; e) Eusmilia fastigiata forma guacanayabensis, holotype, $\times 1.5$. Credit: B. Jablensky (images $a-d$ ); S. Gonzáles Ferrer (image $e$ ).

tice, supporting the methodology and usage of unconventional taxonomy in the study of Cuban Scleractinia. Two decades after our monograph questioned the species status of Acropora prolifera, genetics proved its hybrid nature. Intriguingly, a visit to the same places 30 years later (Zlatarski et al., 2004, Zlatarski, 2010) showed that coral species richness re- mains high, with a notably more frequent presence of the hybrid, even in new places in the lagoon, where its fragments formed the basis of build-ups. The opportunistic nature of this coral hybrid became evident even more so in Gran Banco de Buena Esperanza (GBBE), where after at least four decades the hybrid was proliferating with only parent species, revealing 
a previously unknown but important aspect of coral evolution, and a timely one in the struggle for saving coral reefs (Zlatarski and González Ferrer, 2017). The knowledge obtained during our investigation was fundamental to: developing a holistic approach to scleractinian species (Zlatarski, 2007); contributing on the integrative character of scleractinian taxonomy (Zlatarski, 2009); examining paleobiological perspectives on the variability and taxonomy of scleractinian corals (Zlatarski, 2010); reviewing past, present and future tasks in Scleractinia research (Zla-

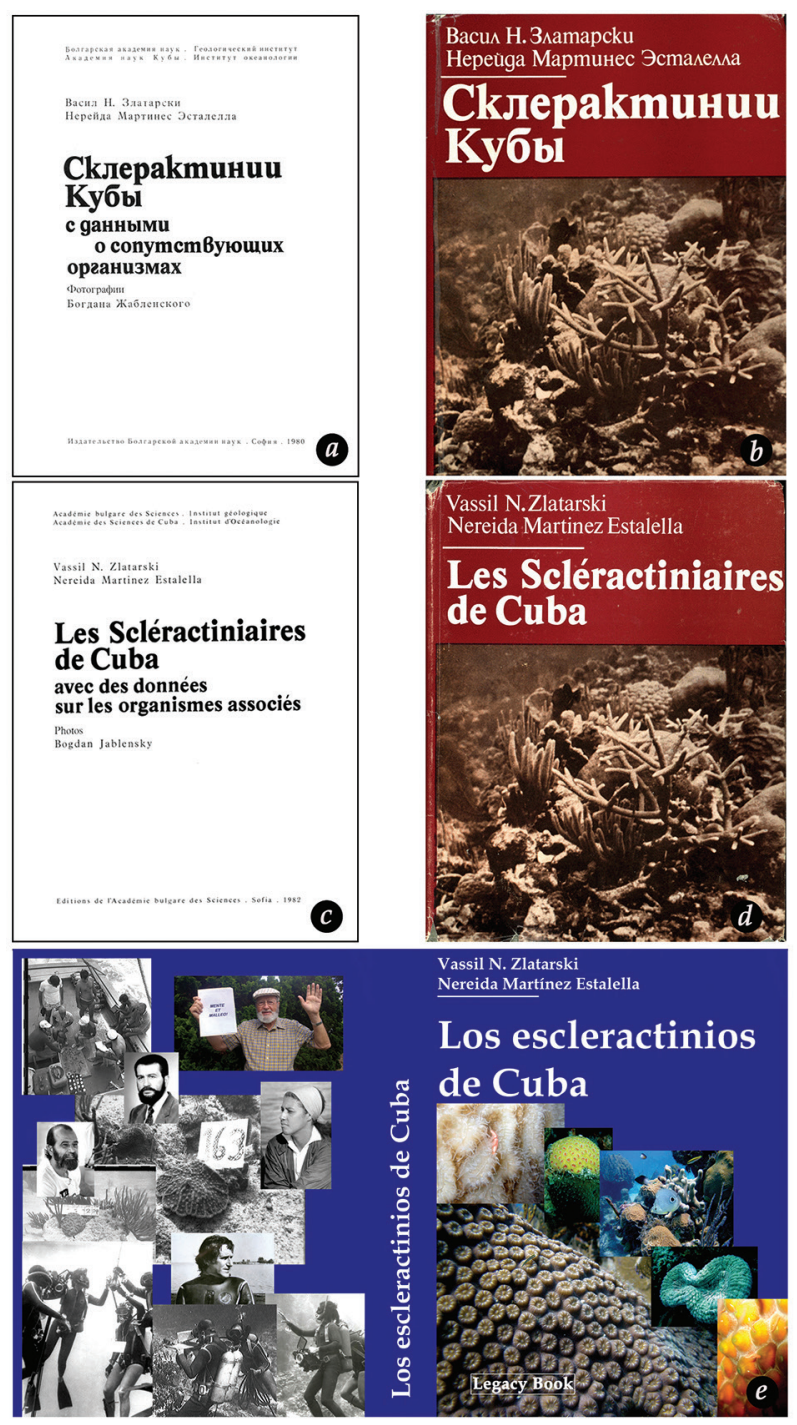

Fig. 2. Covers and title page of the versions of The Scleractinians of Cuba: a) Title page of Russian version; $b$ ) Front cover of Russian version; $c$ ) Title page of French version; $d$ ) Front cover of French version; e) Cover of upcoming Spanish version with photographs illustrating the work and participants of the investigation: middle, Alberto Korda and Nereida Martínes Estalella; bottom, Bogdan Jablensky; top, the author at the time of the investigation and today. Credit: S. Gonzáles Ferrer (e). tarski, 2012); proposing a conceptual model of contemporary scleractinian research (Zlatarski, 2014); and, in the context of skeletal morphogenesis, understanding the idiosyncrasy of the self-organized shape of reticulate reefs and paleobiological interpretations (Zlatarski and González Ferrer, 2017).

Remarkably, $80 \%$ of the collection, with all identifying data, is preserved in Havana's Acuario Nacional (Anonymous, 2009) and available for review and comparison with present- and future-day coral and reef life. Information about the collection and the history of the investigation was illustrated (González Ferrer, 2004). Thanks to Professor Joseph Pawlik (University of North Carolina Wilmington), our documentary was made freely available on YouTube, as a two-way actuopaleontological tool for Anthropocene, in a new series called "Reefs of the Past" at https://youtu.be/ DMa-82-bIwU.

Language barriers limited the use of the French and Russian monographs by Cubans and other interested Spanish speakers. The goals of Professor John W. Tunnel, Jr., and the Harte Research Institute at Texas A\&M University-Corpus Christi's to disseminate knowledge and support sustainable use and conservation of the Gulf of Mexico honored the monograph, in a new Spanish version, as the first of a series of Legacy Books (Fig. 2), and generously made the publication possible.

Taxonomic decisions have changed and improved with sampling strategies and progress in research methods. Naturally, updates were required for the new Spanish version. An author's note in Spanish and English will provide an explanation of these updates.

The preserved collection and documentary film, the availability of a Spanish version of the book, the opened key taxonomic questions and at the same time the preservation and availability of excellent material for their clarification, together with an unexplored unique reef system demonstrating the evolutionary benefit of coral hybridization for reef survival, collectively maintain this investigation in progress, and to be continued.

In retrospect, this ongoing actuopaleontological investigation is a result of a combination of serendipity and a dreamer's tenacity. I am immensely grateful for the privilege of having collaborated with so many extraordinary people, across time and geography, and experiencing with them the coral paradise.

\section{Acknowledgements}

Thanks to Prof. Kristalina Stoykova for supporting the idea for this article and to Dr. L. Metodiev, Chief Editor of Geologica Balcanica, for his kind attention and assistance. I am grateful to B. Jablensky and to S. González Ferrer for their photographs and assistance with illustrations and to my daughter, Vera, for improving the text. 


\section{REFERENCES}

Beauvais, L., Zlatarski, V. 1966. Actinoseris? alloiteaui sp. n., Madréporaire du Crétacé inférieur de la Bulgarie. Comptes rendus de l'Académie bulgare des Sciences 19 (12), 11711173.

Cousteau, J.-Y., Diolé, P.H. 1971. La vie et la mort des coraux. Flammarion, Paris, 306 pp.

González Ferrer, S. 2004. Corales pétreos, jardines sumergidos de Cuba. Editorial Academia, La Habana, 318 pp.

Khrischev, Kh., Zlatarski, V. 1968. Organic structures in the Urgonian sediments in Central Fore-Balkan. Jubilee Geological Volume, Geological Institute, Bulgarian Academy of Sciences and Committee on Geology, Sofia, 113-120 (in Bulgarian, with English abstract).

Zlatarski, V. 1966. Enallhelia multiradiata sp. n., Madréporaire du Crétacé inférieur de la Bulgarie. Comptes rendus de l'Académie bulgare des Sciences 19 (2), 145-147.

Zlatarski, V. 1967a. Note sur le genre Clausastrea d'Orbigny (ordre Madreporaria). Bulletin of the Geological Institute, Series Paleontology 16, 23-34.

Zlatarski, V. 1967b. Dimorphocoeniopsis beauvaisorum, une nouvelle espèce Madreporaria du Crétacé inférieur de la Bulgarie du Nord. Comptes rendus de l'Académie bulgare des Sciences 20 (12), 1317-1320.

Zlatarski, V. 1967c. II. All-Union Symposium on the Study of Fossil Corals of the U.S.S.R. Priroda 16 (6), 85-86 (in Bulgarian).

Zlatarski, V. 1968a. Diplocteniopsidae, une nouvelle famille de Madreporaria de l'Aptien de la Bulgarie du Nord. Bulletin of the Geological Institute, Series Paleontology 17, 49-107.

Zlatarski, V. 1968b. Paraclausastrea, un nouveau genre de Madreporaria de l'Aptien de la Bulgarie du Nord. Review of the Bulgarian Geological Society 29 (2), 159-171.

Zlatarski, V. 1968c. Paleobiology of the Urgonian Scleractinia of the Central Fore-Balkan. PhD thesis, Bulgarian Academy of Sciences and Committee on Geology, Sofia, 264 pp. (in Bulgarian).

Zlatarski, V, 1969. State of art of scleractinian taxonomy. Review of the Bulgarian Geological Society 30 (1), 99-101 (in Russian).

Zlatarski, V. 1970. Cyclastraea meltensis, nouvelle espèce de Madreporaria de l'Aptien de Bulgarie. Comptes rendus de l'Académie bulgare des Sciences 23 (2), 201-204.

Zlatarski, V. 1972. Hydnophora ackermanni, une nouvelle espèce de Madreporaria du Crétacé inférieur de la Bulgarie. Review of the Bulgarian Geological Society 33 (2), 267-269, pl. I.

Zlatarski, V.N (with contributions of J.P. Chevalier, P.P. Duarte-Bello, O.F. Geyer, G. Gill, E.V. Krasnov, E. Mory- cowa, A. Russo, J.W. Wells). 1973. Glossary of equivalent terms for scleractinian (Madreporaria) studies in English, German, French, Italian, Spanish, Polish, Russian, Bulgarian. Fossil Cnidaria, International Newsletter, CNRS, Paris, 2, 34-55.

Zlatarski, V. 1975. On the coral fauna of Cuba. Transactions of the Institute of Geology and Geophysics, Ancient Cnidaria 202, 231-236 (in Russian, with English abstract).

Zlatarski, V. 1983. The Scleractinians of Cuba. Summary of DSc thesis, Paleontological Institute, Academy of Sciences USSR, Moscow, 35 pp. (in Russian).

Zlatarski, V. 2002. The reticulated reefs in Golfo de Guacanayabo, Cuba, and bioconstructions in the "Urgonian", Bulgaria. ISRS European Meeting, Cambridge, p. 110.

Zlatarski, V. 2007. The scleractinian species - a holistic approach. In: Hubmann, B., Piller, W.E. (Eds), Fossil Corals and Sponges. Proceedings of the 9th International Symposium on Fossil Cnidaria and Porifera. Österreichische Akademie der Wissenschaften, Schriftenreiche der Erdwissenschaftlichen Kommission 17, Wien, 523-531.

Zlatarski, V. 2009. Need for a more integrative approach to scleractinian taxonomy. In: Riegl, B. and Dodge, R. (Eds), Proceedings of the 11th International Coral Reef Symposium, Ft. Lauderdale, Florida, 1412-1416.

Zlatarski, V. 2010. Palaeobiological perspectives on variability and taxonomy of scleractinian corals. Palaeoworld 19 (3-4), 333-339.

Zlatarski, V. 2014. Conceptual model of the integrative character of contemporary scleractinian research. Reef Encounter 29 (2), 63-64.

Zlatarski, V., González Ferrer, S. 2017. Gran Banco de Buena Esperanza: unique Caribbean coral reef system. Reef Encounter, 45, 60-62.

Zlatarski, V., Martínez Estalella, N. 1980. The Scleractinians of Cuba with data of associated organisms. Bulgarian Academy of Sciences, Sofia, 312 pp. (in Russian).

Zlatarski, V., Martinez Estalella, N. 1982. Les Scléractiniares de Cuba avec des données sur les organismes associés. Académie bulgare des Sciences, Sofia, 472 pp.

Zlatarski, V., Stake, J.L. 2012. The scleractinian corals: a perspective. Geologica Belgica 1 (4), 370-375.

Zlatarski, V., Alcolado, P.M., González Ferrer, S., Kramer, P. 2004. Archipiélago Jardines de la Reina, Cuba. Thirty years later, species richness of scleractinian corals remains high. Reef Encounter, 32, 30-32.

Anonymous. 2009. Colección de Corales pétreos de Cuba. Acuario Nacional de Cuba \& UCI ISBN 978-959-300-007-9. 